\title{
Colorectal Cancer pT1 TNM Finding v8
}

National Cancer Institute

\section{Source}

National Cancer Institute. Colorectal Cancer pT1 TNM Finding v8. NCI Thesaurus. Code C134160.

Colorectal cancer with tumor invading the submucosa (through the muscularis mucosa but not into the muscularis propria). (from AJCC 8th Ed.) 